\title{
An invasion risk map for non-native aquatic macrophytes of the Iberian Peninsula
}

\author{
Argantonio Rodríguez-Merino ${ }^{1 *}$, Rocío Fernández-Zamudio ${ }^{2} \&$ Pablo García-Murillo $^{1}$ \\ ${ }^{1}$ Department of Plant Biology and Ecology, Faculty of Pharmacy, University of Seville, Profesor García González St., no. 2, 41012 Seville, Spain; \\ argantonio.rodriguez@gmail.com \\ ${ }^{2}$ Doñana Biological Station, CSIC, Américo Vespucio Ave., s.n., 41092 Seville, Spain
}

\begin{abstract}
Rodríguez-Merino, A., Fernández-Zamudio, R. \& García-Murillo, P. 2017. An invasion risk map for non-native aquatic macrophytes of the Iberian Peninsula. Anales Jard. Bot. Madrid 74(1): e055.

Freshwater systems are particularly susceptible to non-native organisms, owing to their high sensitivity to the impacts that are caused by these organisms. Species distribution models, which are based on both environmental and socio-economic variables, facilitate the identification of the most vulnerable areas for the spread of non-native species. We used MaxEnt to predict the potential distribution of 20 non-native aquatic macrophytes in the Iberian Peninsula. Some selected variables, such as the temperature seasonality and the precipitation in the driest quarter, highlight the importance of the climate on their distribution. Notably, the human influence in the territory appears as a key variable in the distribution of studied species. The model discriminated between favorable and unfavorable areas with high accuracy. We used the model to build an invasion risk map of aquatic macrophytes for the Iberian Peninsula that included results from 20 individual models. It showed that the most vulnerable areas are located near to the sea, the major rivers basins, and the high population density areas. These facts suggest the importance of the human impact on the colonization and distribution of non-native aquatic macrophytes in the Iberian Peninsula, and more precisely agricultural development during the Green Revolution at the end of the 70's. Our work also emphasizes the utility of species distribution models for the prevention and management of biological invasions.
\end{abstract}

Keywords: Aquatic plants, bioclimatic factors, biological invasions, ecological niche models, freshwater ecosystems, map risk assessment, MaxEnt, non-native species, socio-economic factors, species distribution model.

\section{Resumen}

Rodríguez-Merino, A., Fernández-Zamudio, R. \& García-Murillo, P. 2017. Mapa de riesgo de invasión de macrófitos acuáticos exóticos de la Península Ibérica. Anales Jard. Bot. Madrid 74(1): e055.

Los sistemas acuáticos son especialmente susceptibles a los organismos exóticos debido a su elevada fragilidad y a los impactos que provocan estas especies en este tipo de hábitats. Los modelos de distribución de especies, basados en variables ambientales y socioeconómicas, facilitan la identificación de las áreas más vulnerables ante la expansión de especies exóticas. Se utilizó MaxEnt para predecir la distribución potencial de 20 macrofitos exóticos en la Península Ibérica. Algunas de las variables estudiadas, como la estacionalidad de la temperatura y la precipitación del cuatrimestre más seco, ponen en evidencia la importancia de los factores climáticos en su distribución. Además, la influencia humana en el territorio se presenta como una variable clave en la distribución de las especies estudiadas. El modelo obtenido discrimina claramente entre áreas favorables y desfavorables con mucha precisión. Se utilizó el modelo para construir un mapa de riesgo de invasión de macrófitos acuáticos para la Península Ibérica que incluyó los resultados de 20 modelos individuales y que muestra que las áreas más vulnerables son las zonas cercanas al mar, las cuencas de los grandes ríos y las zonas con una alta densidad de población. Estos resultados vinculan la importancia del impacto humano en la colonización y la distribución de los macrófitos acuáticos exóticos en la Península Ibérica y, más concretamente, con la Revolución Verde de finales de la década de los setenta. Nuestro trabajo enfatiza la utilidad de los modelos de distribución de especies para la prevención y gestión de invasiones biológicas.

Palabras clave: Ecosistemas acuáticos continentales, especies exóticas, factores bioclimáticos, factores socioeconómicos, invasiones biológicas, mapa de evaluación de riesgos, MaxEnt, modelos de nicho ecológico, modelos de distribución de especies, plantas acuáticas.

ORCID ID: A. Rodríguez-Merino (http://orcid.org/0000-0002-1568-5087); R. Fernández-Zamudio (http://orcid.org/0000-0001-5804-9518); P. GarcíaMurillo (http://orcid.org/0000-0002-1761-9569).

Received: 10-VIII-2016; accepted: 10-I-2017; published online: 30-5-2017; Associate Editor: Leopoldo Medina.

Copyright: (C) 2017 CSIC. This is an open-access article distributed under the terms of the Creative Commons Attribution-Non Commercial (by-nc) Spain 3.0 License.

\section{INTRODUCTION}

Invasive species are one of the main causes of biodiversity loss. At a global scale, they represent a major threat to the ecosystems functioning (Mack \& al., 2000; Sala \& al., 2000; Brooks \& al., 2004). Non-native species may also cause negative effects (Ricciardi \& Kipp, 2008; Pyšek \& Richardson, 2010) on human health (Hulme, 2006; Chytrý \& al., 2009), as well as important economic impacts (Pimentel \& al., 2005). Some freshwater systems are considered biodiversity hotspots (Murphy, 2002; Strayer \& Dudgeon, 2010; Brundu, 2015; Serrano \& Díaz Paniagua, 2015) and are one of the most threatened ecosystems in the world (Collen \& al., 2014; Brundu, 2015; Serrano \& Díaz Paniagua, 2015). These systems are particularly susceptible to biological invasions, because of their propensity to shift away from natural conditions and feedbacks that alter colonized habitats (Willby, 2007; Aguiar \& Ferreira, 2013; Brundu, 2015; Gallardo \& al., 2015). Aquatic macrophytes

* Corresponding author 
play an important role in the structure and function of freshwater systems (Chambers \& al., 2008; García-Murillo \& Fernández-Zamudio, 2015) by providing a structurally complex environment (Rennie \& Jackson, 2005; Dibble \& al., 2006). They contribute to environmental heterogeneity (Harrel \& Dibble, 2001) and to increase the diversity of ecological niches. Aquatic invaders features like high productivity, broad ecological tolerances, notable phenotypic plasticity, and a remarkable facility in producing propagules (Santamaría, 2002; Les \& al., 2003), have led some invasive freshwater plants to belong to the group of the "100 of the World's Worst Invasive Alien Species" (Lowe $\&$ al., 2004). In addition, the nutrient increase in many water bodies due to human activities and the frequent absence of natural enemies in this group of plants, have led in some cases to absolute dominance in the invaded habitats (García-Murillo \& al., 2007; Ruiz \& al., 2008).

An early detection of the arrival of non-native species can increase the success in their eradication before the establishment, preventing future invasions (Broennimann \& Guisan, 2008; Williams \& Grosholz, 2008; Crafton, 2015). For this reason, it should be necessary to identify the most exposed areas of invasion risk (Reshetnikov \& Ficetola, 2011). But aquatic habitats in general and aquatic macrophytes in particular are difficult to be monitored (Brundu, 2015). So, the development and use of alternative methodologies for the prevention and control of exotic species are essential for the identification of areas with a high invasion risk. This kind of methodologies will allow us to manage potential non-native species while preserving native species (Gallardo \& al., 2012).

Species distribution models have the potential to predict invasiveness and have become common in the study and management of biological invasions (Peterson, 2003; Thuiller \& al., 2005). Significant recent advances have been achieved in the development of species distribution models (v.gr., Elith \& Leathwick, 2009). Appropriate factors in modeling the potential distribution of species, as well as the use of suitable occurrence data, are essential to execute more accurate models. In our case, we have chosen the algorithm MaxEnt (Phillips \& al., 2006), based on the maximum entropy principle, for modeling the potential distribution of non-native aquatic macrophytes. Several authors propose that MaxEnt model is better than other algorithms based on presence-only data (Elith \& al., 2006; Elith \& Leathwick, 2009; Mateo \& al., 2010).

The Iberian Peninsula has been considered as a plant biodiversity hotspot (Molina \& al., 2015), including aquatic plants (Chappuis \& al., 2012). But over the last decades a significant transformation seems to have occurred in some important Iberian inland aquatic ecosystems. In essence, we have observed an expansion of some non-native aquatic plants and the decrease in some other native ones (Cirujano \& al., 2014). The aim of this study is to predict the potential priority risk areas for invasion of aquatic plants in the Iberian Peninsula. To accomplish this objective we have employed a species distribution model. We firstly determined the influence of environmental and socio-economic factors over 20 non-native aquatic macrophytes at a global scale. Secondly, we overlapped the individual models to achieve a map that shows the higher vulnerable areas, due to the effect of multiple invasions.
Finally, we compared the most vulnerable regions with the irrigated agricultural areas in order to find an explanation for the distribution of the studied species.

\section{MATERIAL AND METHODS}

\section{Study area}

The Iberian Peninsula is located in the southwestern Europe. It is restricted by the Atlantic Ocean and the Mediterranean Sea. The Pyrenees separate it from the rest of Europe, and the Strait of Gibraltar from Africa. The climate diversity of the study area and the rugged topography of the land along with the geographic isolation, are key elements to develop an outstanding biodiversity (López-López \& al., 2011). Concerning aquatic plants, this territory shows a high diversity of aquatic ecosystems and water bodies. Thus, we can find several types of rivers, streams, creeks, lakes, ponds - temporary or permanent - , bogs, and marshlands.

\section{Species selection}

We have modeled the distribution of 20 non-native aquatic macrophytes which are currently established in the Iberian Peninsula (Table 1). The non-native species belong to 13 genus and 9 families and were selected from Cirujano \& al. (2014) complemented with the European and Mediterranean Plant Protection Organization list -EPPO, see http://www.eppo.int - and the Delivering Alien Invasive Species Inventories for Europe list -DAISIE, see http://www.europe-alien.org.

The global spatial occurrences of 20 species were obtained from the Global Biodiversity Information Facility (GBIF, 2015). We tested the Iberian Peninsula occurrences with data showed by the Anthos Project (Anthos, 2015). The case of Ludwigia peploides subsp. montevidensis (Spreng.) P.H. Raven was checked in other additional sources (Verloove \& Sánchez, 2008; Bou \& Font, 2016). Records were considered from 1950 to the present to match the timeframe for the current climate data. In order to avoid underestimating the potential niche we counted all occurrences available for each species, showing the native and invasive ranges of species (Jiménez-Valverde \& al., 2011).

We used the statistical software R (R Development Core Team, 2014) to clean data and removed duplicates, data without date, and erroneous occurrences in both taxonomic and geographic data. Furthermore, we also reduced the spatial autocorrelation of the data to not violate the assumption of independence (Heffner \& al., 1996). Thus, the distance between data pairs was reduced to $10 \mathrm{~km}$; the same distance was used for modeling the species' potential distribution.

\section{Predictor variables}

The 19 bioclimatic layers and altitude -Digital Elevation Model, DEM - were taken from WorldClimGlobal Climate Data (Hijmans \& al., 2005; Worldclim, 2015). The resolution of the environmental layers used was 5 arc-min $-\sim 10 \mathrm{~km}$ at the equator. 
Table 1. List of non-native aquatic macrophytes selected for the Iberian Peninsula.

\begin{tabular}{|c|c|c|}
\hline Family & Genus & Species \\
\hline Azollaceae & Azolla & A. filiculoides Lam. (incl. A. caroliniana Willd.) \\
\hline \multirow[t]{3}{*}{ Araceae } & Lemna & L. minuta Kunth \\
\hline & & L. valdiviana Phil. \\
\hline & Pistia & P. stratiotes L. \\
\hline \multirow[t]{2}{*}{ Haloragaceae } & Myriophyllum & M. aquaticum (Vell.) Verdc. \\
\hline & & M. heterophyllum Michx. \\
\hline \multirow{2}{*}{ Hydrocharitaceae } & Elodea & E. canadensis Michx. \\
\hline & Lagarosiphon & L. major (Ridley) Moss ex Wager \\
\hline Nymphaeaceae & Nymphaea & N. mexicana Zucc. \\
\hline \multirow[t]{2}{*}{ Onagraceae } & Ludwigia & L. grandiflora (Michx.) Greuter \& Burdet \\
\hline & & L. peploides subsp. montevidensis (Spreng.) P.H. Raven \\
\hline \multirow{2}{*}{ Pontederiaceae } & & H. reniformis Ruiz \& Pav. \\
\hline & & H. rotundifolia (Kunth) Griseb. \\
\hline \multirow[t]{2}{*}{ Apiaceae } & Hydrocotyle & H. ranunculoides $\mathrm{L} . \mathrm{f}$. \\
\hline & & H. verticillata Thunb. \\
\hline Salviniaceae & Salvinia & S. natans (L.) All. \\
\hline
\end{tabular}

Slope was derived from DEM layer using the software ArcGIS 9.3.1 (ESRI, 2008). The human footprint was considered a socio-economic factor that reflects the human influence on the territory following Sanderson \& al. (2002). This authors used as proxies of this footprint several variables such as various human land uses, population density or distance to major roads, railways and rivers. The information was obtained from Socioeconomic Data and Applications Center (SEDAC, 2015) and its resolution is 30 arc-sec $-1 \mathrm{~km}$.

The resolution of 22 variables (Table 2) was turned into 5 arc-min and was projected using the World Geodetic System 1984 projection. The spatial correlation between variables was analyzed by Raster package (Hijmans \& van Etten, 2015). After obtaining the correlation tree, the variables were selected by a threshold limit of 0.5 . In addition, to remove the linear combination between variables in the model, the Variance Inflation Factor - VIF - was calculated using the package $\mathrm{HH}$, and taking 5 as limit value (Heiberger, 2015).

\section{Species distribution modeling}

We developed the species distribution models with the machine learning MaxEnt version 3.3.3.k (Phillips \& al., 2006), which estimates species distribution by the principle of maximum entropy. This method was chosen because is one of the most effective species distribution model, and shows a high quality achievement with low sample sizes and moderate georeferencing errors (Elith \& al., 2006; Wisz \& al., 2008; Mateo \& al., 2010).

The parameters employed for this study were taken from Phillips \& al. (2006), Phillips \& Dudík (2008), and Elith \& al. (2011). Default parameters were convergence threshold $=0.00001$, maximum iterations $=1,000$, and
Table 2. List and description of used variables.

\begin{tabular}{|c|c|}
\hline Variable & Description \\
\hline Bio 1 & Annual mean temperature \\
\hline Bio 2 & $\begin{array}{l}\text { Mean diurnal range [mean of monthly (max temp - min } \\
\text { temp)] }\end{array}$ \\
\hline Bio 3 & Isothermality [(Bio $2 /$ Bio 7) $* 100]$ \\
\hline Bio 4 & Temperature seasonality \\
\hline Bio 5 & Maximum temperature of warmest month \\
\hline Bio 6 & Minimum temperature of coldest month \\
\hline Bio 7 & Temperature annual range (Bio 5 - Bio 6) \\
\hline Bio 8 & Mean temperature of wettest quarter \\
\hline Bio 9 & Mean temperature of driest quarter \\
\hline Bio 10 & Mean temperature of warmest quarter \\
\hline Bio 11 & Mean temperature of coldest quarter \\
\hline Bio 12 & Annual precipitation \\
\hline Bio 13 & Precipitation of wettest month \\
\hline Bio 14 & Precipitation of driest month \\
\hline Bio 15 & Precipitation seasonality (coefficient of variation) \\
\hline Bio 16 & Precipitation of wettest quarter \\
\hline Bio 17 & Precipitation of driest quarter \\
\hline Bio 18 & Precipitation of warmest quarter \\
\hline Bio 19 & Precipitation of coldest quarter \\
\hline DEM & Digital Elevation Model \\
\hline Slope & Slope \\
\hline HFP & Human Footprint \\
\hline
\end{tabular}

prevalence $=0.5$, multiple regularization - default is $1-$ was changed to 2.5 to reduce the probability of overfitting models following Elith \& al. (2010). Models were fitted with the $70 \%$ occurrences data and the remaining $30 \%$ was used to 
evaluate the obtained models. Besides, we used 10-fold crossvalidations to estimate the errors around the fitted functions and the predictive performance on the held-out data (Elith \& al., 2011). We created 10,000 background points to simulate pseudo-absences (Phillips \& Dudík, 2008; Elith \& al., 2011). Likewise, we interpreted the logistic output as a habitat suitability map for each species. The model accuracy was estimated using the area under the receiving operating characteristic - ROC - curve - AUC - According to it, the results within a value of 0.5 do not discriminate better than the random, while a model with a perfect discrimination would have an AUC of 1, and values bigger or equal than 0.7 correspond to the highest predictive models (Hosmer \& Lemeshow, 2000). Finally, we calculated the AUC for each model and determined the average AUC for each set of 10 replicates (Barnes $\&$ al., 2014). $10^{\text {th }}$ percentile training presence threshold was chosen because it shows a good ability to predict correctly the presence of invasive species (Pearson \& al., 2007; Reshetnikov \& Ficetola, 2011), representing the species distribution in suboptimal habitats (Kelly \& al., 2014).

\section{Invasion risk map}

The invasion risks map was calculated by overlaying the 20 species distribution individual models (Aranda \& Lobo, 2011; Fajardo \& al., 2014) using the Geographic Information System ArcGIS 9.3.1 (ESRI, 2008). Thereby we obtained a cartography that reflects the cumulative risk of invasion, which represent the most favorable areas for colonization and spread for the studied species in the Iberian Peninsula.

\section{RESULTS}

A total of 8,892 records were used for modeling the global potential distribution of species. The number of records varied widely among species - Nymphaea mexicana Zucc. minimum global occurrence points: 46 and Azolla filiculoides Lam. maximum occurrence points: 1,617, after cleaning data- Fig. 1 shows the number of records per decade and the accumulated number of records per decade, and Fig. 2 shows the current presences of studied species on the Iberian Peninsula.

The final factors included as predictors in MaxEnt were mean diurnal range - Bio 2-, temperature seasonality (Bio 4), annual precipitation - Bio 12-, precipitation seasonality - Bio 15-, precipitation in the driest quarter -Bio 17-, altitude, slope, and human footprint - HFP.

In Table 3 we show the main results for each studied species. The accuracy scores of models ranged between 0.918 and 0.981 , which shows that our models provide a good performance (Hosmer \& Lemeshow, 2000) indicating a better discrimination than random chance for the species analyzed (Phillips \& al., 2006). The binomial test of omission showed statistical significance $-p<0.001-$ for each of the 10 replicates (Phillips \& al., 2006), supporting the reliability of the models. The use of $10^{\text {th }}$ percentile training presence threshold allowed us to discriminate correctly the presence of non-native species (Pearson \& al., 2007; Reshetnikov \& Ficetola, 2011) in both optimal and suboptimal areas (Jiménez-Valverde \& al., 2011; Kelly \& al., 2014).

The best predictor of potential distribution for the majority of the species was the human footprint. In relation to Azolla filiculoides, Hydrocotyle verticillata Thunb., Lagarosiphon major (Ridl.) Moss ex Wager, and Pistia stratiotes L., the best predictor was the temperature seasonality; for Heteranthera rotundifolia (Kunth) Griseb. the mean diurnal range, and for Myriophyllum heterophyllum Michx. the precipitation in the driest quarter. Besides, for these species the human footprint was included among the three best predictors (Table 3).

The suitable habitat models for the invasion risk varied broadly between species (Fig. 2), showing a large favorable distribution for species as Azolla filiculoides,

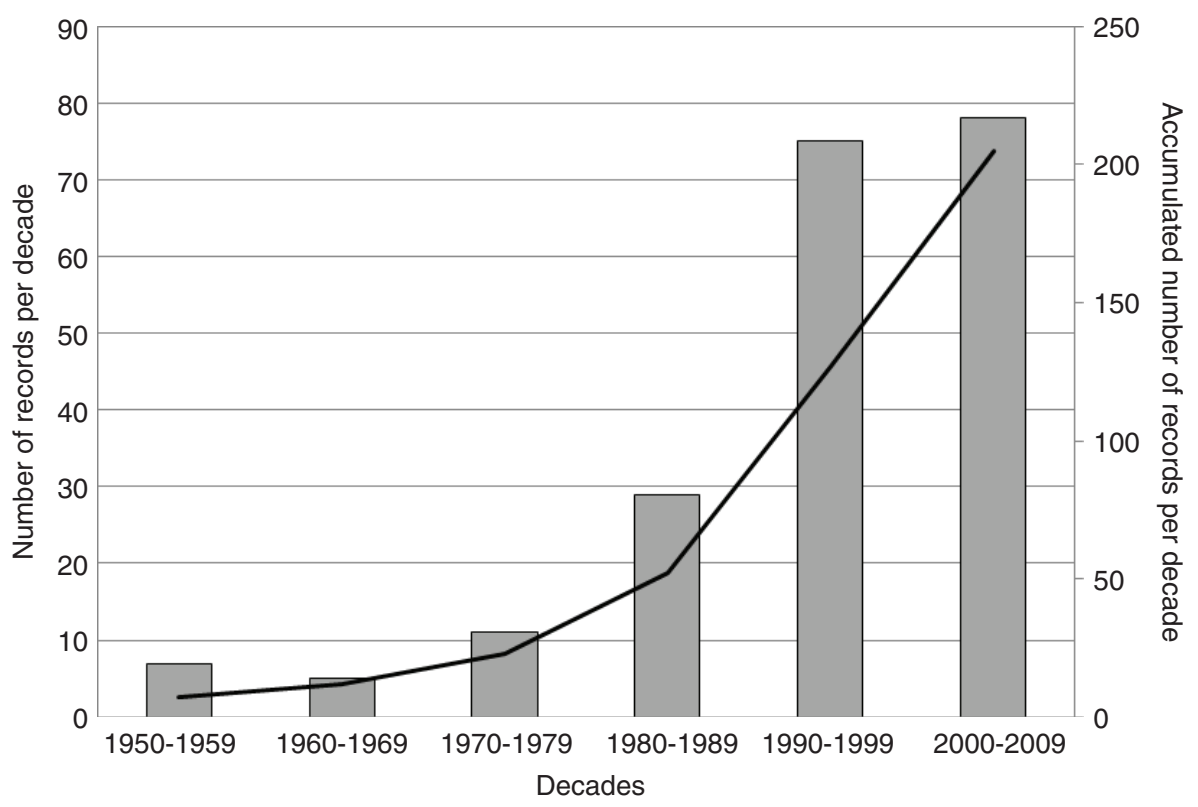

Fig. 1. Number of records per decade and accumulated number of records per decade of all the aquatic macrophytes studied in the Iberian Peninsula. 


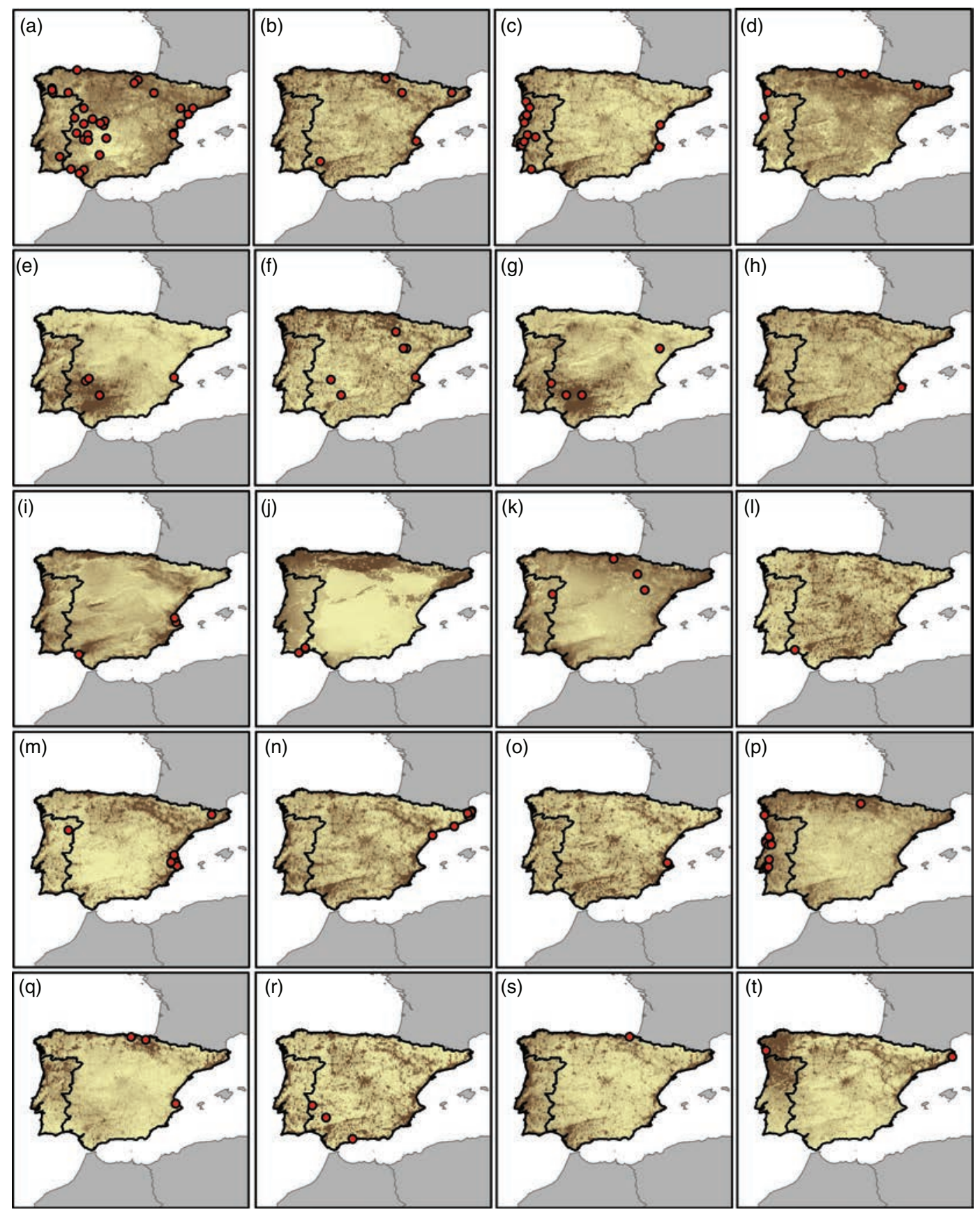

Fig. 2. Potential distribution models for the selected species: a, Azolla filiculoides; b, Egeria densa; c, Eichhornia crassipes; d, Elodea canadensis; e, Heteranthera limosa; $\mathbf{f}$, Heteranthera reniformis; $\mathbf{g}$, Heteranthera rotundifolia; $\mathbf{h}$, Hydrocotyle ranunculoides; $\mathbf{i}$, Hydrocotyle verticillata; $\mathbf{j}$, Lagarosiphon major; k, Lemna minuta; l, Lemna valdiviana; $\mathbf{m}$, Ludwigia grandiflora; $\mathbf{n}$, Ludwigia peploides subsp. montevidensis; $\mathbf{0}$, Ludwigia repens; $\mathbf{p}$, Myriophyllum aquaticum; q, Myriophyllum heterophyllum; r, Nymphaea mexicana; s, Pistia stratiotes; $\mathbf{t}$, Salvinia natans. Darker areas correspond with higher suitability areas; red spots indicate the presence of occurrences of the studied species in the Iberian Peninsula — after data cleaning process.

Egeria densa Planch., Elodea canadensis Michx., Lemna valdiviana Phil., Nymphaea mexicana, and Ludwigia repens J.R. Forst.

The combination of the 20 individual models is the risk map for non-native Iberian aquatic macrophytes (Fig. 3). It shows the suitability of presence of the species according to the factors selected in the model building. The most vulnerable areas coincide with the littoral fringe, the high population density sectors, and the large river basins.

Fig. 4 shows the overlapping between the irrigated agricultural areas taken from European Environment Agency
(2015) and the most vulnerable region in the invasion risk map.

\section{DISCUSSION}

Our results show the first geographical representation of the potential invasion risk by non-native aquatic macrophytes in the Iberian Peninsula. The combination of both environmental and socio-economic factors allows us to identify those areas more susceptible to be invaded by non-native aquatic plants. 
Table 3. AUC values \pm SD and percent contribution of each of the variables taken into account for the models. In bold the best factor in the potential distribution of each species.

\begin{tabular}{|c|c|c|c|c|c|c|c|c|c|}
\hline \multirow[b]{2}{*}{ Species } & \multirow[b]{2}{*}{$\mathrm{AUC} \pm \mathrm{SD}$} & \multicolumn{8}{|c|}{ Variables } \\
\hline & & Bio 2 & Bio 4 & Bio 12 & Bio 15 & Bio 17 & Altitude & Slope & $\mathrm{HFP}$ \\
\hline A. filiculoides & $0.923 \pm 0.003$ & 0.3 & 43.9 & 4.2 & 18.6 & 1.6 & 1.2 & 0.0 & 29.6 \\
\hline E. densa & $0.956 \pm 0.009$ & 1.5 & 20.3 & 2.4 & 1.9 & 12.6 & 1.5 & 1.1 & 58.7 \\
\hline E. crassipes & $0.918 \pm 0.014$ & 2.6 & 33.2 & 15.4 & 1.2 & 4.3 & 6.7 & 0.4 & 36.3 \\
\hline E. canadensis & $0.919 \pm 0.008$ & 0.2 & 20.3 & 5.2 & 11.4 & 25.9 & 0.8 & 0.1 & 36.1 \\
\hline H. limosa & $0.956 \pm 0.016$ & 18.4 & 15.6 & 15.4 & 8.4 & 8.5 & 2.7 & 1.7 & 29.4 \\
\hline H. ranunculoides & $0.940 \pm 0.014$ & 1.9 & 26.7 & 5.4 & 5.0 & 1.2 & 4.0 & 0.9 & $\mathbf{5 5 . 0}$ \\
\hline H. reniformis & $0.952 \pm 0.009$ & 1.9 & 30.5 & 21.9 & 2.5 & 5.1 & 0.2 & 3.8 & 34.0 \\
\hline H. rotundifolia & $0.960 \pm 0.012$ & 26.6 & 11.0 & 21 & 5.5 & 9.1 & 2.4 & 2.2 & 22.3 \\
\hline H. verticillata & $0.947 \pm 0.011$ & 9.8 & 49.4 & 1.4 & 6.7 & 3.2 & 9.3 & 2.0 & 18.3 \\
\hline L. major & $0.971 \pm 0.004$ & 16.2 & 27.9 & 4.0 & 19.8 & 6.7 & 0.2 & 0.1 & 25.1 \\
\hline L. minuta & $0.944 \pm 0.007$ & 4.3 & 19.5 & 4.0 & 28.0 & 7.7 & 3.5 & 0.0 & 32.9 \\
\hline L. valdiviana & $0.932 \pm 0.031$ & 18.5 & 11.1 & 2.9 & 1.0 & 6.1 & 0.4 & 6.4 & 53.7 \\
\hline L. grandiflora & $0.981 \pm 0.005$ & 1.1 & 22.4 & 1.0 & 15.0 & 16.7 & 6.9 & 0.5 & 36.4 \\
\hline L. peploides subsp. montevidensis & $0.936 \pm 0.014$ & 6.7 & 32.0 & 2.1 & 2.9 & 4.2 & 3.8 & 1.2 & 47.2 \\
\hline L. repens & $0.937 \pm 0.029$ & 11.8 & 21.5 & 1.3 & 0.7 & 1.2 & 3.5 & 2.6 & $\mathbf{5 7 . 4}$ \\
\hline M. aquaticum & $0.948 \pm 0.005$ & 0.5 & 27.6 & 2.1 & 2.1 & 20.6 & 5.7 & 0.2 & 41.2 \\
\hline M. heterophyllum & $0.973 \pm 0.012$ & 3.9 & 14.0 & 20.9 & 13.5 & 23.7 & 2.9 & 0.7 & 20.4 \\
\hline N. mexicana & $0.967 \pm 0.031$ & 4.2 & 24.0 & 1.2 & 1.8 & 1.7 & 0.4 & 0.6 & 66.0 \\
\hline P. stratiotes & $0.919 \pm 0.010$ & 1.1 & 39.0 & 26.0 & 1.4 & 0.3 & 13.4 & 0.5 & 18.3 \\
\hline S. natans & $0.966 \pm 0.013$ & 6.8 & 16.8 & 4.8 & 4.5 & 22.9 & 1.5 & 1.1 & 41.6 \\
\hline
\end{tabular}

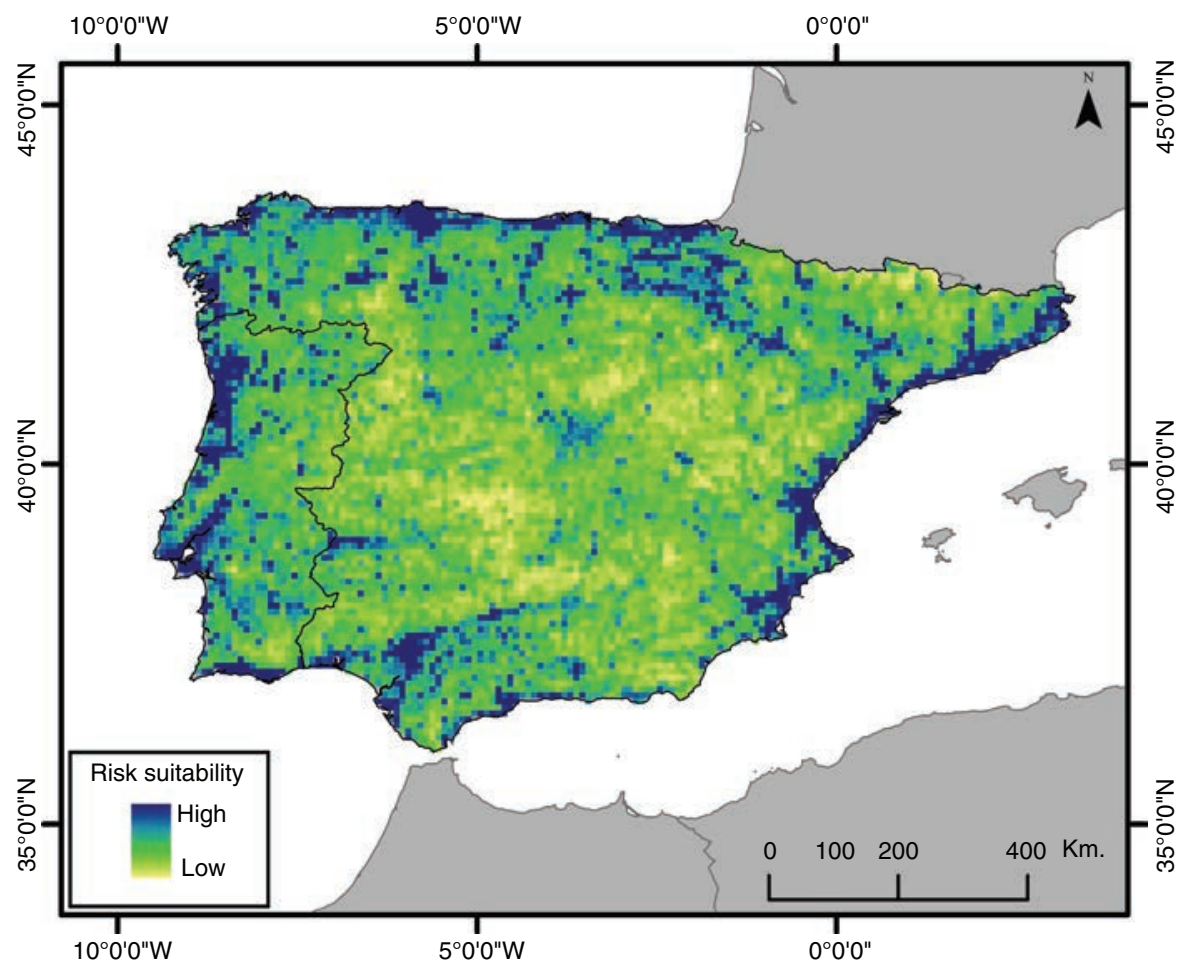

Fig. 3. Invasion risk map representing the risk suitability of 20 non-native aquatic macrophytes species in the Iberian Peninsula.

Large areas of the Iberian Peninsula were suitable to the invasion by different non-native aquatic macrophytes, like Azolla filiculoides, Egeria densa, Elodea canadensis, Lemna valdiviana, Ludwigia repens, Myriophyllum aquaticum (Vell.) Verdc., and Nymphaea mexicana (Fig. 2). Most of them are widely distributed in Europe, being Azolla filiculoides and Elodea canadensis the species present in more European countries (Hussner, 2012).

Temperature seasonality and precipitation in the driest quarter are key factors in the probability distribution of 


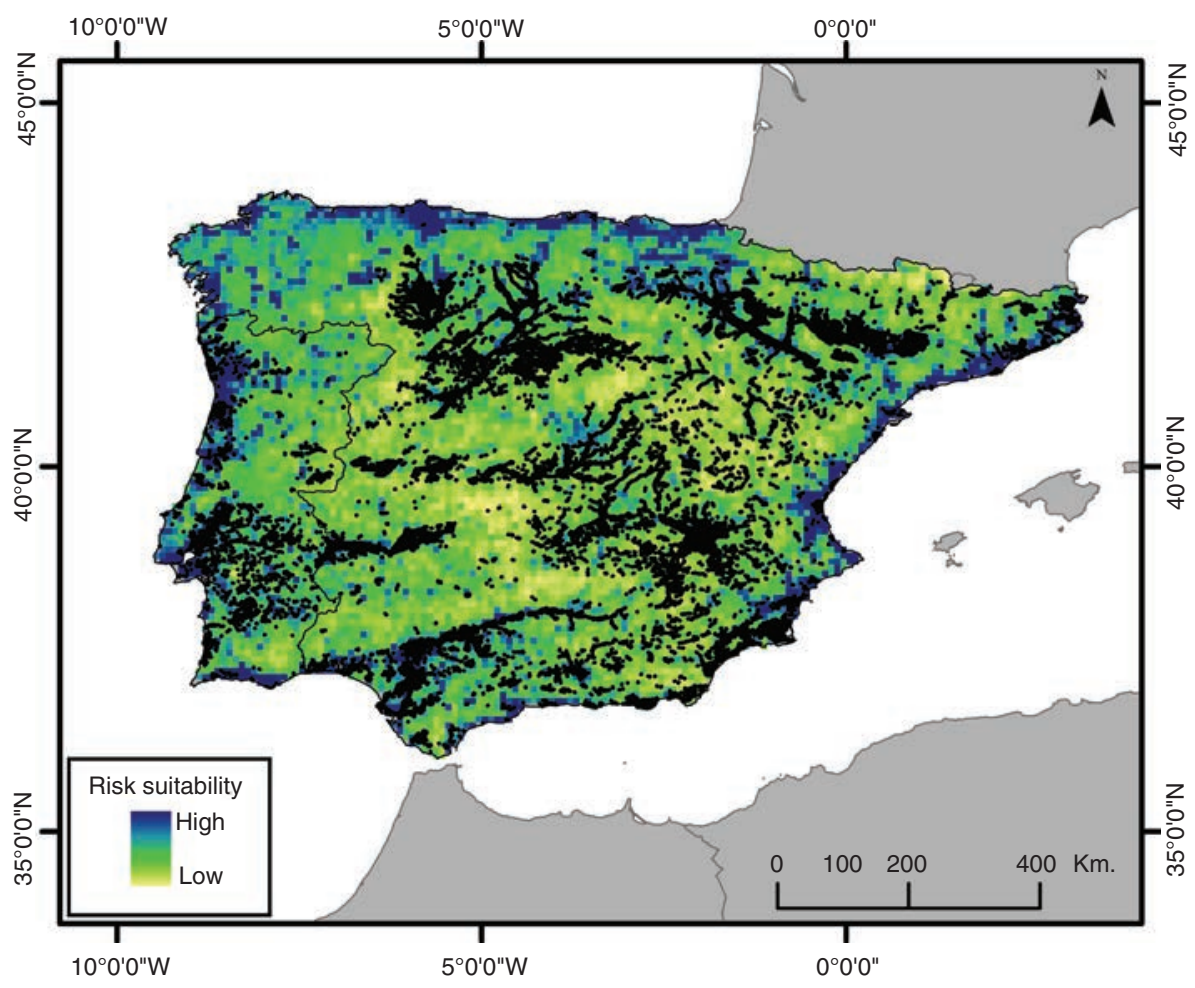

Fig. 4. Map showing the irrigated agricultural areas — black polygons — over suitable habitats for 20 non-native aquatic macrophyte species.

the studied species. This result is supported by the fact that the climatic characteristics of an area act as key elements for a successful colonization of non-native species (Thuiller \& al., 2005; Broennimann \& al., 2007). For instance, the temperature could limit the survival, growth, and reproduction in plants (Woodward \& Willians, 1987), and the precipitation in the driest quarter is associated to water availability of water bodies (Reshetnikov \& Ficetola, 2011), which acts as the principal factor for the persistence of aquatic plants communities. Similar results were obtained by others authors (Gallardo \& Aldridge, 2013; Barnes \& al., 2014; Kelly \& al., 2014), implying that non-native aquatic macrophytes are able to tolerate a wide range of environmental conditions - v.gr., seasonality in Mediterranean environments - and extreme events. This ability benefits them versus native species (Rahel \& Olden, 2008; Gallardo \& Aldridge, 2013). Several authors (Pearson \& Dawson, 2003; Broennimann \& al., 2007; Walther \& al., 2009) have suggested that shifts in climate could benefit non-native species, which often tolerate temperature and precipitation ranges broader than the native ones.

The human footprint was positively associated with the presence of all studied species. This association reflects the easiness these species have to establish in disturbed habitats (Chytrý \& al., 2009; Kelly \& al., 2014), due to the increased presence of introduction vectors and pathways like as channels, roads or railways by which these species can be introduced and the disturbances in land uses in the studied area by human activity (Catford \& al., 2011; Gallardo \& Aldridge, 2013).

For example, the increase of nutrients on watercourses and water bodies, which contributes to the growth of algal blooms and the rise of turbidity levels (Carter \&
Rybicki, 1990; Santamaría \& al., 1996) is associated with human activities. It provokes the reduction of light and oxygen availability, stopping the growth of the submerged vegetation (Moss, 1990) but enhancing floating aquatic macrophytes (Egerston \& al., 2004). The new ecological scheme will promote the establishment of nonnative macrophytes, which are able to colonize degraded habitats, where native macrophytes are unable to survive (Quinn \& al., 2001; Catford \& Downes, 2010; Chappuis \& al., 2011).

Areas under the highest risk of multiple invasions include large rivers basins, highly populated areas, and the coastline (Fig. 3). An important part of the areas for colonization and expansion of these non-native species coincide with territories with agricultural development increase over the last decades. From 1970, the number of records of non-native species in the Iberian Peninsula began to rise (Fig. 1). This period overlaps with the industrialization of agriculture - the Green Revolutionwhen traditional non-irrigated farming was transformed into huge irrigation areas (Ruiz \& al., 2008) in the Iberian Peninsula.

In this period, the high dependence on agricultural chemicals has affected freshwater ecosystems (Galil \& al., 2007). Hydrological alterations and the increase of dissolved nutrients, have contributed to the eutrophication of aquatic ecosystems (Chappuis \& al., 2011; Quinn \& al., 2011), and the intensive land use has favored sedimentation events (Allan, 2004). All these changes have facilitated the expansion of non-native aquatic macrophytes (Egertson \& al., 2004; Chappuis \& al., 2011; Quinn \& al., 2011). Moreover, the increment of sedimentation events caused by an intensive land use also benefits submerged non-native species. Principal 
areas of irrigated agriculture in the Iberian Peninsula overlap with the most susceptible areas to be invaded by non-native macrophytes (Fig. 4). This phenomenon has been reported previously by García-Murillo \& al. (2007) and Ruiz \& al. (2008) for Azolla filiculoides and Eichhornia crassipes (Mart.) Solms expansion, respectively. Both studies support the hypothesis, together with ours, that the quick expansion of non-native macrophytes is due to the nutrients increase contributed by adjacent agricultural areas.

In addition, we also have observed that some areas predicted as being suitable (Fig. 3) were currently unoccupied - see Fig. 2, current presences of studied species-. This may be due to different causes: areas where species have been successfully eradicated - v.gr., Pistia stratiotes in neighborhood Doñana National Park, Southern Spain, as pointed up by García-Murillo \& al. (2005) - or areas with geographical barriers or species interactions that limited its distributions - v.gr., Azolla filiculoides has not been detected in temporary ponds and marshes in Doñana National Park while the weevil Stenopelmus rufinasus Gyllenhal was present in samples, as pointed up by Florencio \& al. (2015) - . Besides, they can also be areas where species have not been detected yet due to the lack of studies in these places, or because this species may have not been able to colonize these suitable areas yet (Liu \& al., 2011) as a consequence of they are still in the early stages of the invasion process. These two last points are crucial for proper management and early control of nonnative species.

Among the species studied in this work, we consider that the most harmful are Azolla filiculoides and Eichhornia crassipes, both present in the major part of the World, being the two more potentially invasive species in Europe and the Mediterranean basin (Hussner, 2012; Kriticos \& Brunel, 2016). Their invasion capacity is due not only to climate tolerance and the adapting ability to eutrophic environments, but also to a high rate of vegetative reproduction that ensure the success of colonization in invaded habitats and a high competition with others species (Ruiz \& al., 2008; Fernández-Zamudio \& al., 2013).

In conclusion, our study, based on the global distribution of 20 non-native aquatic macrophyte species, contributes to the understanding of the distribution patterns of non-native aquatic macrophytes in the Iberian Peninsula, and it may be used as a base to develop useful tools to manage successfully the Iberian biodiversity in future conservation planning, and for the conservation and management of aquatic ecosystems in other lands. Species distribution models should not be a substitute for field work, but they are a first step that allows an early identification of the most vulnerable areas to implement more effective management efforts preventing biological invasions.

\section{ACKNOWLEDGEMENTS}

We are indebted to Professor Timothy H Keitt and Dr. Laura I. González, from the University of Texas, for their comments of the manuscript and for the English revision. Also, we thanks to associate editor and two anonymous reviewers which provided helpful recommendations that improved substantially our manuscript.

\section{REFERENCES}

Aguiar, F.C.F. \& Ferreira, M.T. 2013. Plant invasions in the rivers of the Iberian Peninsula, south-western Europe: A review. Plant Biosystems 147: 1107-1119. https://doi.org/10.1080/11263504.2013.861539.

Anthos [2015]. Spanish Plant Information System. Real Jardín Botánico de Madrid CSIC-Fundación Biodiversidad [http://www.anthos.es/].

Allan, J.D. 2004. Landscapes and riverscapes: The influence of land use on stream ecosystems. Annual Review of Ecology Evolution and Systematics 35: 257-284. https://doi.org/10.1146/annurev. ecolsys.35.120202.110122.

Aranda, S.C. \& Lobo, J.M. 2011. How well does presence-only-based species distribution modelling predict assemblage diversity? A case study of the Tenerife flora. Ecography 34: 31-38. https://doi. org/10.1111/j.1600-0587.2010.06134.x.

Barnes, M.A., Jerde, C.L., Wittmann, M.E., Chadderton, W.L., Ding, J., Zhang, J., Purcell, M., Budhathoki, M. \& Lodge, D.M. 2014. Geographic selection bias of occurrence data influences transferability of invasive Hydrilla verticillata distribution models. Ecology and Evolution 4: 2584-2593. https://doi.org/10.1002/ece3.1120.

Bou, J. \& Font, J. 2016. Situation in Catalonia of Ludwigia peploides (Onagraceae). Butlletí de la Institució Catalana d' Historia Natural 80: 57-58.

Broennimann, O. \& Guisan, A. 2008. Predicting current and future biological invasions: both native and invaded ranges matter. Biology Letters 4: 585-589. https://doi.org/10.1098/rsbl.2008.0254.

Broennimann, O., Treier, U.A., Muller-Scharer, H., Thuiller, W., Peterson, A.T. \& Guisan, A. 2007. Evidence of climatic niche shift during biological invasion. Ecology Letters 10: 701-709. https://doi. org/10.1111/j.1461-0248.2007.01060.x.

Brooks, M.L., D’Antonio, C.M., Richardson, D.M., Grace, J.B., Keeley, J.E., DiTomaso, J.M., Hobbs, R.J., Pellant, M. \& Pyke, D. 2004. Effects of invasive alien plants on fire regimes. BioScience 54: 677-688. https://doi.org/10.1641/0006-3568(2004)054[0677:EOIAPO] 2.0.CO;2.

Brundu, G. 2015. Plant invaders in European and Mediterranean inland waters: profiles, distribution, and threats. Hydrobiologia 746: 61-79. https://doi.org/10.1007/s10750-014-1910-9.

Carter, V. \& Rybicki, N.B. 1990. Light attenuation and submersed macrophyte distribution in the tidal Potomac River and estuary. Estuaries 13: 441-452. https://doi.org/10.2307/1351788.

Catford, J.A. \& Downes, B.J. 2010. Using multi-scale species distribution data to infer drivers of biological invasion in riparian wetlands. Diversity and Distributions 16: 20-32. https:/doi. org/10.1111/j.1472-4642.2009.00631.x.

Catford, J.A., Vesk, P.A., White, M.D. \& Wintle, B.A. 2011. Hotspots of plant invasion predicted by propagule pressure and ecosystem characteristics. Diversity and Distributions 17: 1099-1110. https://doi. org/10.1111/j.1472-4642.2011.00794.x.

Chambers, P.A., Lacoul, P., Murphy, K.J. \& Thomaz, S.M. 2008. Global diversity of aquatic macrophytes in freshwater. Hydrobiologia 595: 9-26. https://doi.org/10.1007/s10750-007-9154-6.

Chappuis, E., Gacia, E. \& Ballesteros, E. 2011. Changes in aquatic macrophyte flora over the last century in Catalan water bodies (NE Spain). Aquatic Botany 95: 268-277. https://doi.org/10.1016/j. aquabot.2011.08.006

Chappuis, E., Ballesteros, E. \& Gacia, E. 2012. Distribution and richness of aquatic plants across Europe and Mediterranean countries: patterns, environmental driving factors and comparison with total plant richness. Journal of Vegetation Science 23: 985-997. https://doi. org/10.1111/j.1654-1103.2012.01417.x.

Chytrý, M., Pyšek, P., Wild, J., Pino, J., Maskell, L.C. \& Vilà, M. 2009. European map of alien plant invasions based on the quantitative assessment across habitats. Diversity and Distributions 15: 98-107. https://doi.org/10.1111/j.1472-4642.2008.00515.x

Cirujano, S., Meco, A., García-Murillo, P. \& Chirino Argenta, M. 2014 Flora Acuática Española. Hidrófitos Vasculares. Real Jardín Botánico de Madrid CSIC, Madrid.

Collen, B., Whitton, F., Dyer, E.E., Baillie, J.E.M., Cumberlidge, N., Darwall, W.R.T., Pollock, C., Richman, N.I., Soulsby, A.M. \& Böhm, M. 2014. Global patterns of freshwater species diversity, threat and endemism. Global Ecology and Biogeography 23: 40-51. https://doi. org/10.1111/geb.12096.

Crafton, R. E. 2015. Modeling invasion risk for coastal marine species utilizing environmental and transport vector data. Hydrobiologia 746 349-362. https://doi.org/10.1007/s10750-014-2027-x. 
Dibble, E.D., Thomaz, S.M. \& Padial, A.A. 2006. Spatial complexity measured at a multi-scale in three aquatic plant species. Journal of Freshwater Ecology 21: 239-247. https://doi.org/10.1080/02705060. 2006.9664992.

Egertson, C.J., Kopaska, J.A. \& Downing, J.A. 2004. A century of change in macrophyte abundance and composition in response to agricultural eutrophication. Hydrobiologia 524: 145-156. https://doi.org/10.1023/ B:HYDR.0000036129.40386.ce.

Elith, J. \& Leathwick, J.R. 2009. Species distribution models: ecological explanation and prediction across space and time. Annual Review of Ecology, Evolution, and Systematics 40: 677-697. https://oi. org/10.1146/annurev.ecolsys.110308.120159.

Elith, J., Kearney, M. \& Phillips, S. 2010. The art of modelling rangeshifting species. Methods in Ecology and Evolution 1: 330-342. https:// doi.org/10.1111/j.2041-210X.2010.00036.x.

Elith, J., Phillips, S.J., Hastie, T., Dudík, M., Chee, Y.E. \& Yates, C.J. 2011. A statistical explanation of MaxEnt for ecologists. Diversity and Distributions 17: 43-57. https://doi.org/10.1111/j. 1472-4642.2010.00725.x.

Elith, J., Graham, C.H., Anderson, R.P., Dudik, M., Ferrier, S., Guisan, A., Hijmans, R.J., Huettmann, F., Leathwick, J.R., Lehmann, A., Li, J., Lohmann, L.G., Loiselle, B.A., Manion, G., Moritz, C., Nakamura, M., Nakazawa, Y., Overton, J.M., Peterson, A.T., Phillips, S.J., Richardson, K., Scachetti-Pereira, R., Schapire, R.E., Soberon, J., Williams, S., Wisz, M. \& Zimmermann, N.E. 2006. Novel methods improve prediction of species' distributions from occurrence data. Ecography 29: 129-151. https://doi.org/10.1111/j.2006.0906-7590.04596.x.

ESRI. 2008. ArcGIS Desktop: Release 9.3. Environmental Systems Research Institute, United States of America.

European Environment Agency [2015]. Corine Land Cover dataset [http:// www.eea.europa]

Fajardo, J., Lessmann, J., Bonaccorso, E., Devenish, C. \& Muñoz, J. 2014. Combined use of systematic conservation planning, species distribution modeling, and connectivity analysis reveals severe conservation gaps in a megadiverse country (Peru). Plos One 9: 1-23. https:// doi.org/10.1371/journal.pone.0114367.

Fernández-Zamudio, R., Cirujano, S., Sánchez-Carrillo, S., Meco, A. \& García-Murillo, P. 2013. Clonal reproduction of Azolla filiculoides Lam.: implications for invasiveness. Limnetica 32: 245-252.

Florencio, M., Fernández-Zamudio, R., Bilton, D.T. \& Díaz-Paniagua, C. 2015. The exotic weevil Stenopelmus rufinasus Gyllenhal, 1835 (Coleoptera: Curculionidae) across a "host-free" pond network. Limnetica 34: 79-84.

Galil, B.S., Nehring, S. \& Panov, V. 2007. Waterways as invasion highways impact of climate change and globalization. Biological Invasions. W. Nentwig, Springer, Berlin.

Gallardo, B. \& Aldridge, D.C. 2013. The dirty dozen: socio-economic factors amplify the invasion potential of 12 high-risk aquatic invasive species in Great Britain and Ireland. Journal of Applied Ecology 50: 757-766. https://doi.org/10.1111/1365-2664.12079.

Gallardo, B., Errea, M.P. \& Aldridge, D. 2012. Application of bioclimatic models coupled with network analysis for risk assessment of the killer shrimp, Dikerogammarus villosus, in Great Britain. Biological Invasions 14: 1265-1278. https://doi.org/10.1007/s10530-011-0154-0.

Gallardo, B., Clavero, M., Sánchez, M.I. \& Vilà, M. 2015. Global ecological impacts of invasive species in aquatic ecosystems. Global Change Biology 22: 1-13.

García-Murillo, P., Dana, E.D. \& Rodríguez, C. 2005. Pistia stratiotes L. (Araceae) Una planta acuática exótica en las proximidades del Parque Nacional de Doñana (SW España). Acta Botanica Malacitana 30: 235-236.

García-Murillo, P., Fernández-Zamudio, R., Cirujano, S., Sousa, A. \& Espinar, J.M. 2007. The invasion of Doñana National Park (SW Spain) by the mosquito fern (Azolla filiculoides Lam.). Limnetica 26: 242-250.

García-Murillo, P. \& Fernández-Zamudio, R. 2015. Las plantas de las lagunas temporales de Doñana. In: Díaz Paniagua, C. (coord.), El sistema de lagunas temporales de Doñana, una red de hábitats acuáticos singulares. Organismo Autónomo Parques Nacionales, Madrid.

GBIF [2015]. Global Biodiversity Information Facility Data Portal [http:// www.gbif.org/].

Harrel, S. \& Dibble, E. 2001. Foraging efficiency of juvenile bluegill, Lepomis macrochirus, among different vegetated habitats. Environmental Biology of Fishes 62: 441-453. https://doi.org/10.1023/A:1012259922727.

Heffner, R.A., Butler, M.J. \& Reilly, C.K. 1996. Pseudoreplication revisited. Ecology 77: 2558-2562. https://doi.org/10.2307/2265754.
Heiberger, R.M. [2015]. Statistical analysis and data display: Heiberger and Holland. R package version 3.1-23 [http://cran.r-project.org].

Hijmans, R.J. \& Van Etten, J. 2015. Raster: Geographic analysis and modeling with raster data. $R$ package version 3.1-23 [http://cran.r-project.org].

Hijmans, R.J., Cameron, S.E., Parra, J.L., Jones, P.G. \& Jarvis, A. 2005 Very high resolution interpolated climate surfaces for global land areas. International Journal of Climatology 25: 1965-1978. https://doi. org/10.1002/joc. 1276

Hosmer, D.W. \& Lemeshow, S. 2000. Applied Logistic Regression. John Wiley \& Sons Inc., New York. https://doi.org/10.1002/0471722146.

Hulme, P.E. 2006. Beyond control: wider implications for the management of biological invasions. Journal of Applied Ecology 43: 835-847. https://doi.org/10.1111/j.1365-2664.2006.01227.x.

Hussner, A. 2012. Alien aquatic plant species in European countries. Weed Research 52: 297-306. https://doi.org/10.1111/j.1365-3180.2012.00926.x.

Jiménez-Valverde, A., Peterson, A.T., Soberón, J., Overton, J.M., Aragón, P. \& Lobo, J.M. 2011. Use of niche models in invasive species risk assessments. Biological invasions 13: 2785-2797. https://doi.org/10. 1007/s10530-011-9963-4.

Kelly, R., Leach, K., Cameron, A., Maggs, C.A. \& Reid, N. 2014 Combining global climate and regional landscape models to improve prediction of invasion risk. Diversity and Distributions 20: 1-11. https://doi.org/10.1111/ddi.12194.

Kriticos, D.J. \& Brunel, S. 2016. Assessing and managing the current and future pest risk from water hyacinth, (Eichhornia crassipes), an invasive aquatic plant threatening the environment and water security. Plos One 11: 1-18. https://doi.org/10.1371/journal.pone.0120054.

Les, D.H., Crawford, D.J., Kimball, R.T., Moody, M.L. \& Landolt, E. 2003. Biogeography of discontinuously distributed hydrophytes: A molecular appraisal of intercontinental disjunctions. International Journal of Plant Sciences 164: 917-932. https://doi.org/10.1086/378650.

Liu, X., Guo, Z., Ke, Z., Wang, S. \& Li, Y. 2011. Increasing potential risk of a global aquatic invader in Europe in contrast to other continents under future climate change. Plos One 6: 1-11. https://doi.org/10.1371/ journal.pone.0018429.

Lowe, S.J., Browne, M., Boudjelas, S. \& de Pooter, M. 2004. 100 of the World's Worst Invasive Species Alien Species: a Selection from the Global Invasive Species Database. Published by The Invasive Species Specialist Group (ISSG, SSC, IUCN).

Mack, R.N., Simberloff, D., Mark Lonsdale, W., Evans, H., Clout, M. \& Bazzaz, F.A. 2000. Biotic invasions: causes, epidemiology, global consequences, and control. Ecological Applications 10: 689-710. https:// doi.org/10.1890/1051-0761(2000)010[0689:BICEGC]2.0.CO;2.

Mateo, R.G., Croat, T.B., Felicísimo, A.M. \& Muñoz, J. 2010. Profile or group discriminative techniques? Generating reliable species distribution models using pseudo-absences and target-group absences from natural history collections. Diversity and Distributions 16: 84-94. https://doi.org/10.1111/j.1472-4642.2009.00617.x.

Molina, R., Aparicio, A., Lavergne, S., Slingsby, J. \& Arroyo, J. 2015. Investigating the evolutionary assembly of a Mediterranean biodiversity hotspot: deep phylogenetic sgnal in the distribution of eudicots across elevational belts. Journal of Biogeography 42: 507-518. https:// doi.org/10.1111/jbi.12398.

Moss, B. 1990. Engineering and biological approaches to the restoration from eutrophication of shallow lakes in which aquatic plant communities are important components. Hydrobiologia 200-201: 367-377. https://doi.org/10.1007/BF02530354.

Murphy, K.J. 2002. Plant communities and plant diversity in softwater lakes of northern Europe. Aquatic Botany 73: 287-324. https://doi. org/10.1016/S0304-3770(02)00028-1

López-López, P., Maiorano, L., Falcucci, A., Barba, E. \& Boitani, L. 2011. Hotspots of species richness, threat and endemism for terrestrial vertebrates in SW Europe. Acta Oecologica 37: 399-412. https:// doi.org/10.1016/j.actao.2011.05.004

Pearson, R.G. \& Dawson, T.P. 2003. Predicting the impacts of climate change on the distribution of species: are bioclimate envelope models useful? Global Ecology and Biogeography 12: 361-371. https://doi. org/10.1046/j.1466-822X.2003.00042.x.

Pearson, R.G., Raxworthy, C.J., Nakamura, M. \& Townsend Peterson, A. 2007. Predicting species distributions from small numbers of occurrence records: a test case using cryptic geckos in Madagascar. Journal of Biogeography 34: 102-117. https://doi.org/10.1111/j. 1365-2699.2006.01594.x.

Peterson, A.T. 2003. Predicting the geography of species' invasions via ecological niche modeling. The Quarterly Review of Biology 78: 41933. https://doi.org/10.1086/378926. 
Phillips, S.J. \& Dudík, M. 2008. Modeling of species distributions with MaxEnt: new extensions and a comprehensive evaluation. Ecography 31: 161-175. https://doi.org/10.1111/j.0906-7590.2008.5203.x.

Phillips, S.J., Anderson, R.P. \& Schapire, R.E. 2006. Maximum entropy modeling of species geographic distributions. Ecological Modelling 190: 231-259. https://doi.org/10.1016/j.ecolmodel.2005.03.026.

Pimentel, D., Zuniga, R. \& Morrison, D. 2005. Update on the environmental and economic costs associated with alien-invasive species in the United States. Ecological Economics 52: 273-288. https://doi. org/10.1016/j.ecolecon.2004.10.002.

Pyšek, P. \& Richardson, D.M. 2010. Invasive species, environmental change and management, and health. Annual Review of Environment and Resources 35: 25-55. https://doi.org/10.1146/ annurev-environ-033009-095548.

Quinn, L.D., Schooler, S.S. \& van Klinken, R.D. 2011. Effects of land use and environment on alien and native macrophytes: lessons from a large-scale survey of Australian rivers. Diversity and Distributions 17: 132-143. https://doi.org/10.1111/j.1472-4642.2010.00726.x.

R Development Core Team [2014]. R: a language and environment for statistical computing. Version 3.1.2. Foundation for Statistical Computing, Vienna, Austria [http://cran.r-project.org].

Rahel, F.J. \& Olden, J.D. 2008. Assessing the effects of climate change on aquatic invasive species. Conservation biology 22: 521-533. https://doi. org/10.1111/j.1523-1739.2008.00950.x.

Rennie, M.D. \& Jackson, L.J. 2005. The influence of habitat complexity on littoral invertebrate distributions: patterns differ in shallow prairie lakes with and without fish. Canadian Journal of Fisheries and Aquatic Sciences 62: 2088-2099. https://doi.org/10.1139/f05-123.

Reshetnikov, A. \& Ficetola, G. 2011. Potential range of the invasive fish rotan (Perccottus glenii) in the Holarctic. Biological Invasions 13: 2967-2980. https://doi.org/10.1007/s10530-011-9982-1.

Ricciardi, A. \& Kipp, R. 2008. Predicting the number of ecologically harmful exotic species in an aquatic system. Diversity and Distributions 14: 374-380. https://doi.org/10.1111/j.1472-4642. 2007.00451.x.

Ruiz, T., Martín, E., Lorenzo, G., Albano, E., Morán, R. \& Sánchez, J.M. 2008. The Water Hyacinth, Eichhornia crassipes: an invasive plant in the Guadiana River Basin (Spain). Aquatic Invasions 3: 42-53. https:// doi.org/10.3391/ai.2008.3.1.8.

Sala, O.E., Chapin, F.S., Armesto, J.J., Berlow, E., Bloomfield, J., Dirzo, R., Huber-Sanwald, E., Huenneke, L.F., Jackson, R.B., Kinzig, A. Leemans, R., Lodge, D.M., Mooney, H.A., Oesterheld, M., Poff, N.L., Sykes, M.T., Walker, B.H., Walker, M. \& Wall, D.H. 2000 Global biodiversity scenarios for the year 2100. Science 287: 17701774. https://doi.org/10.1126/science.287.5459.1770.

Sanderson, E.W., Jaiteh, M., Levy, M.A., Redford, K.H., Wannebo, A.V. \& Woolmer, G. 2002. The human footprint and the last of the wild. BioScience 52: 891-904. https://doi.org/10.1641/0006-3568(2002) 052[0891:THFATL]2.0.CO;2.
Santamaría, L. 2002. Why are most aquatic plants widely distributed? Dispersal, clonal growth and small-scale heterogeneity in a stressful environment. Acta Oecologica 23: 137-154. https://doi.org/10.1016/ S1146-609X(02)01146-3.

Santamaría, L., Montes, C. \& Hootsmans, M.J.M. 1996. Influence of environmental parameters on the biomass development of Ruppia drepanensis populations in Doñana National Park: the importance of conditions affecting the underwater light climate. International Journal of Salt Lake Research 5: 157-180. https://doi.org/10.1007/ BF01995828.

SEDAC [2015]. Socioeconomic Data and Applications Center [http:// sedac.ciesin.columbia.edu].

Serrano, L. \& Díaz Paniagua, C. 2015. Introducción. In: Díaz Paniagua, C. (coord.), El sistema de lagunas temporales de Doñana, una red de hábitats acuáticos singulares: 9-18. Organismo Autónomo Parques Nacionales. Madrid.

Strayer, D.L. \& Dudgeon, D. 2010. Freshwater biodiversity conservation: recent progress and future challenges. Journal of the North American Benthological Society 29: 344-358. https://doi.org/10.1899/08-171.1.

Thuiller, W., Richardson, D.M., Pyšek, P., Midgley, G.F., Hughes, G.O. \& Rouget, M. 2005. Niche-based modelling as a tool for predicting the risk of alien plant invasions at a global scale. Global Change Biology 11: 2234-2250. https://doi.org/10.1111/j.1365-2486.2005.001018.x.

Verloove, F. \& Sánchez-Gullón, E. 2008. New records of interesting xenophytes in the Iberian Peninsula. Acta Botanica Malacitana 33: 147-167.

Walther, G.R., Roques, A., Hulme, P.E., Sykes, M.T., Pysek, P., Kuhn, I., Zobel, M., Bacher, S., Botta-Dukat, Z., Bugmann, H., Czucz, B., Dauber, J., Hickler, T., Jarosik, V., Kenis, M., Klotz, S., Minchin, D., Moora, M., Nentwig, W., Ott, J., Panov, V.E., Reineking, B., Robinet, C., Semenchenko, V., Solarz, W., Thuiller, W., Vila, M., Vohland, K. \& Settele, J. 2009. Alien species in a warmer world: risks and opportunities. Trends in Ecology and Evolution 24: 686-693. https://doi.org/10. 1016/j.tree.2009.06.008

Willby, N.J. 2007. Managing invasive aquatic plants: problems and prospects. Aquatic Conservation: Marine and Freshwater Ecosystems 17: 659-665. https://doi.org/10.1002/aqc.913.

Williams, S. \& Grosholz, E. 2008. The invasive species challenge in estuarine and coastal environments: marrying management and science. Estuaries and Coasts 31: 3-20. https://doi.org/10.1007/ s12237-007-9031-6.

Wisz, M.S., Hijmans, R.J., Li, J., Peterson, A.T., Graham, C.H., Guisan, A. \& NCEAS Predicting Species Distribution Working Group. 2008. Effects of sample size on the performance of species distribution models. Diversity and Distributions 14: 763-773. https://doi. org/10.1111/j.1472-4642.2008.00482.x.

Woodward, F.I. \& Williams, B.G. 1987. Climate and plant distribution at global and local scales. Vegetatio 69: 189-197. https://doi.org/10.1007/ BF00038700.

Worldclim [2015]. Global Climate Data [http://www.worldclim.org]. 